Printed in Great Britain

\title{
STUDIES ON MARINE ALGAE OF THE BRITISH ISLES: CERAMIUM SHUTTLEWORTHIANUM (KÜTZ.) SILVA
}

\author{
By Peter S. Dixon
}

Hartley Botanical Laboratories, The University, Liverpool 3

(Text-figs. I-7)

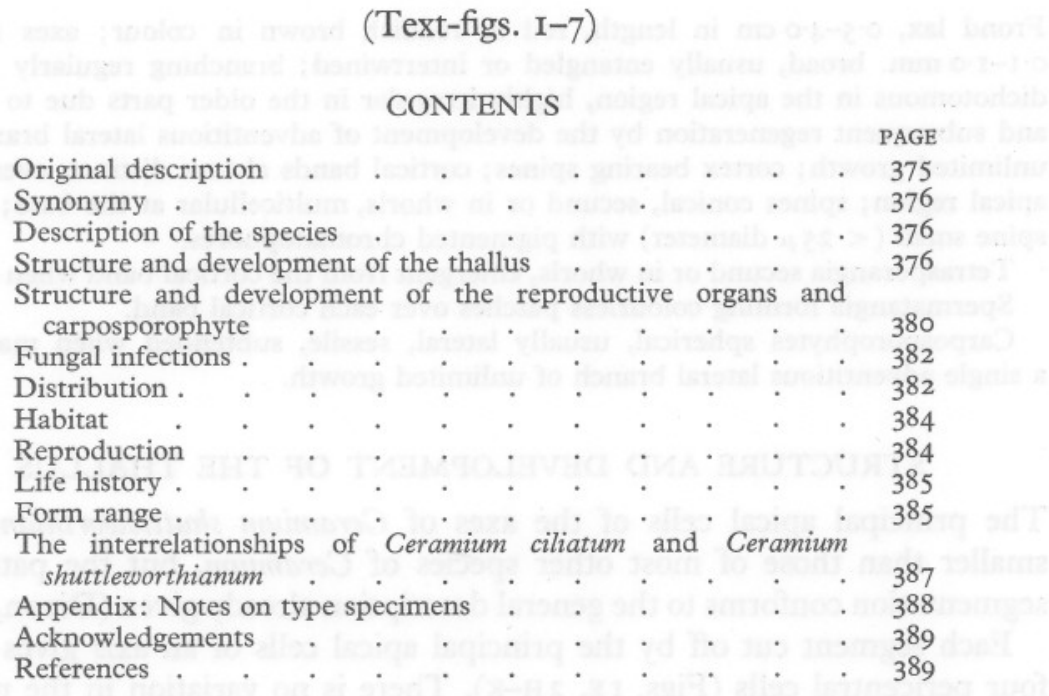

\section{ORIGINAL DESCRIPTION}

The species was first distinguished by Carmichael, as Ceramium acanthonotum, in his unpublished Algae Appinensis, the manuscript of which is now preserved at the Herbarium of the Royal Botanic Gardens, Kew. Harvey (in Hooker, I833), in publishing Carmichael's description, regarded the species merely as a variety of $C$. ciliatum. Agardh (1844) raised the variety to specific status, and it is as $C$. acanthonotum that the species has been known generally. Kützing (I84I), ${ }^{1}$ in a revision of the genus Ceramium, had described the entity independently as Acanthoceras shuttleworthianum; the specific epithet shuttleworthianum has priority over acanthonotum [see Article 60 of the International Code of Botanical Nomenclature (Lanjouw, 1956)]. The priority of the epithet shuttleworthianum was indicated, independently, by both Silva (1959) and Dixon (1959); of the two publications, that by Silva is the earlier.

The original material of $A$. shuttleworthianum is preserved at the Rijksherbarium, Leiden. According to Kützing (184I, p. 739), the species was described on the basis of material 'an der irischen Küsten: Shuttleworth'. In the Kützing herbarium there is a single Irish specimen of $A$. shuttleworthianum attached to a small mussel (Mytilus);

1 For comments as to the precise date of publication, see Dixon (1960, p. 333) 
this has been designated as the type specimen (Herb. Lugd. Bat. 940.265.127). The specimen is labelled only as 'Irland' and no further information is available as to the locality from which it was collected.

\section{SYNONYMY}

Ceramium ciliatum $\beta$ acanthonotum Carm. ex. Harv. (in Hooker, I833, p. 236).

Ceramium acanthonotum (Carm. ex Harv.) J. Agardh (1844, p. 26).

For details of the type material of this entity, see Appendix (p. 388).

\section{DESCRIPTION OF THE SPECIES}

Frond lax, $0.5-4.0 \mathrm{~cm}$ in length, red or reddish brown in colour; axes filiform, $\circ \cdot \mathrm{I}-\mathrm{I} \cdot \mathrm{\textrm {mm }}$. broad, usually entangled or intertwined; branching regularly pseudodichotomous in the apical region, highly irregular in the older parts due to damage and subsequent regeneration by the development of adventitious lateral branches of unlimited growth; cortex bearing spines; cortical bands always distinct, even in the apical region; spines conical, secund or in whorls, multicellular at the base; cells of spine small ( $<25 \mu$ diameter) with pigmented chromatophores.

Tetrasporangia secund or in whorls, emergent from the cortical band when mature.

Spermatangia forming colourless patches over each cortical band.

Carposporophytes spherical, usually lateral, sessile, subtended when mature by a single adventitious lateral branch of unlimited growth.

\section{STRUCTURE AND DEVELOPMENT OF THE THALLUS}

The principal apical cells of the axes of Ceramium shuttleworthianum are smaller than those of most other species of Ceramium, but the pattern of segmentation conforms to the general description already given (Dixon, I960).

Each segment cut off by the principal apical cells of an axis gives rise to four pericentral cells (Figs. IE, $2 \mathrm{H}-\mathrm{K}$ ). There is no variation in the number of pericentral cells produced. The filaments of limited growth arise from the pericentral cells, and their development is restricted so that the length of the cortical bands rarely exceeds $120 \mu$ (Fig. 3 A-C). The enlargement of the axial cells varies enormously, so that the 'index of cortication' is extremely variable. Kützing (I862, p. 29) described Acanthoceras shuttleworthianum $\beta$ longiarticulatum, characterized by the extreme length of the non-corticated axial cells in mature parts of the thallus. The taxonomic status of this entity will be discussed later.

From six to ten segments are produced by the principal apical cells between each pseudo-dichotomy. Mature thalli of this species are of very irregular appearance and only rarely do they exhibit the characteristic pseudo-dichotomous structure found in other species of the genus. Most specimens suffer severe damage either by animal grazing or as a result of the extreme exposure of the environment in which they occur. In addition, infection of the principal apical cells of the axes by Eurychasmidium tumefaciens (see p. 383) occurs frequently (Fig. 6A). The subsequent regeneration of adventitious lateral 
branches of unlimited growth (Fig. I D) results in a tangled mass of irregularly branched axes.

Glandular cells occur frequently in Ceramium shuttleworthianum, although not reported in this species by previous investigators. Development occurs as in other species of the genus, by the direct modification of a superficial cell of the thallus.

The spines of $C$. shuttleworthianum are of very characteristic appearance. During the formation of a spine (Fig. $2 \mathrm{~A}-\mathrm{K}$ ), the apical cell of a lateral branch of limited growth divides rapidly to form a projecting filament of
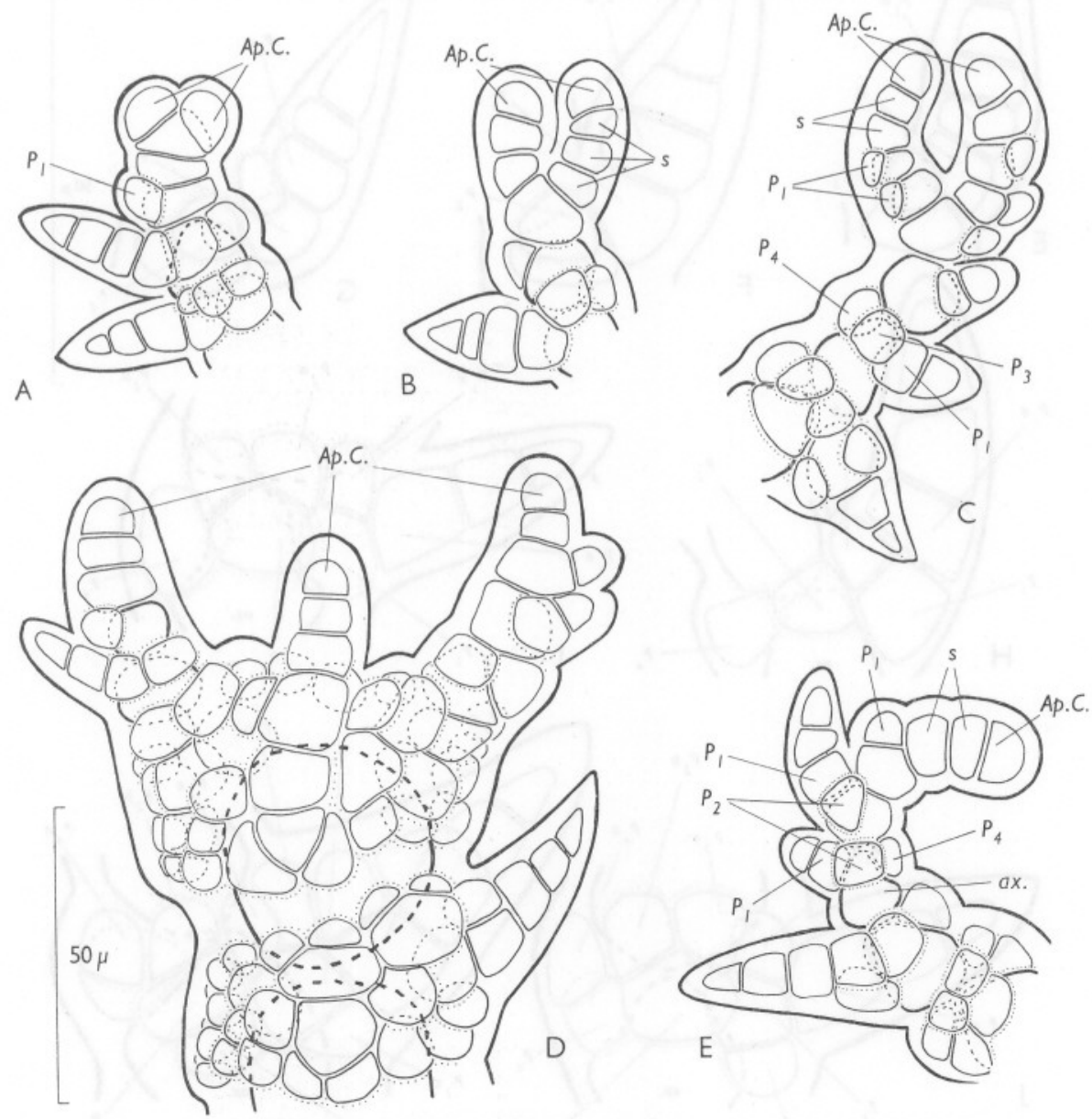

Fig. I. The apex and the origin of lateral branches of unlimited growth in C. shuttleworthianum. A-C, Pseudo-dichotomy of the apex; D, origin of adventitious lateral branches of unlimited growth in a damaged axis; $\mathrm{E}$, the apex of an axis, showing the general pattern of segmentation. Ap.C., apical cell of an axis; ax., axial cell; $P_{1}, P_{2}$, etc., pericentral cells, numbered in order of formation; s., segment, produced by the transverse division of the apical cell of an axis. 


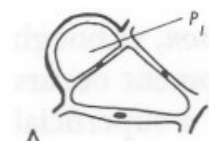

A
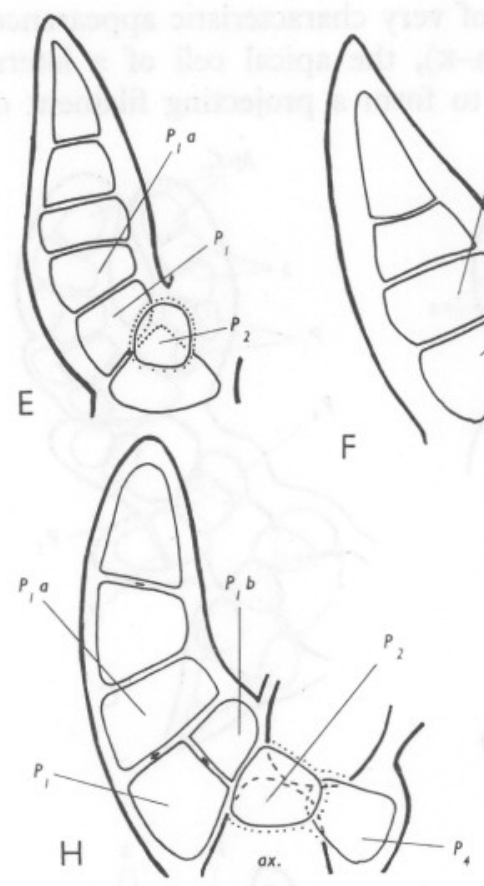

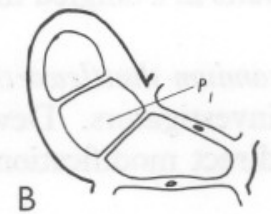

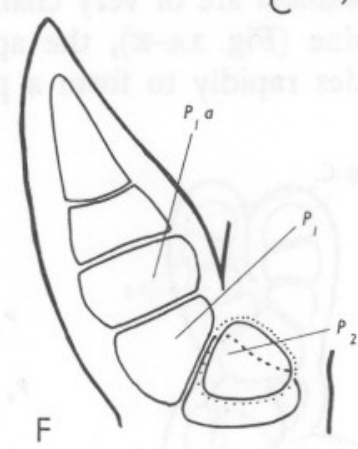
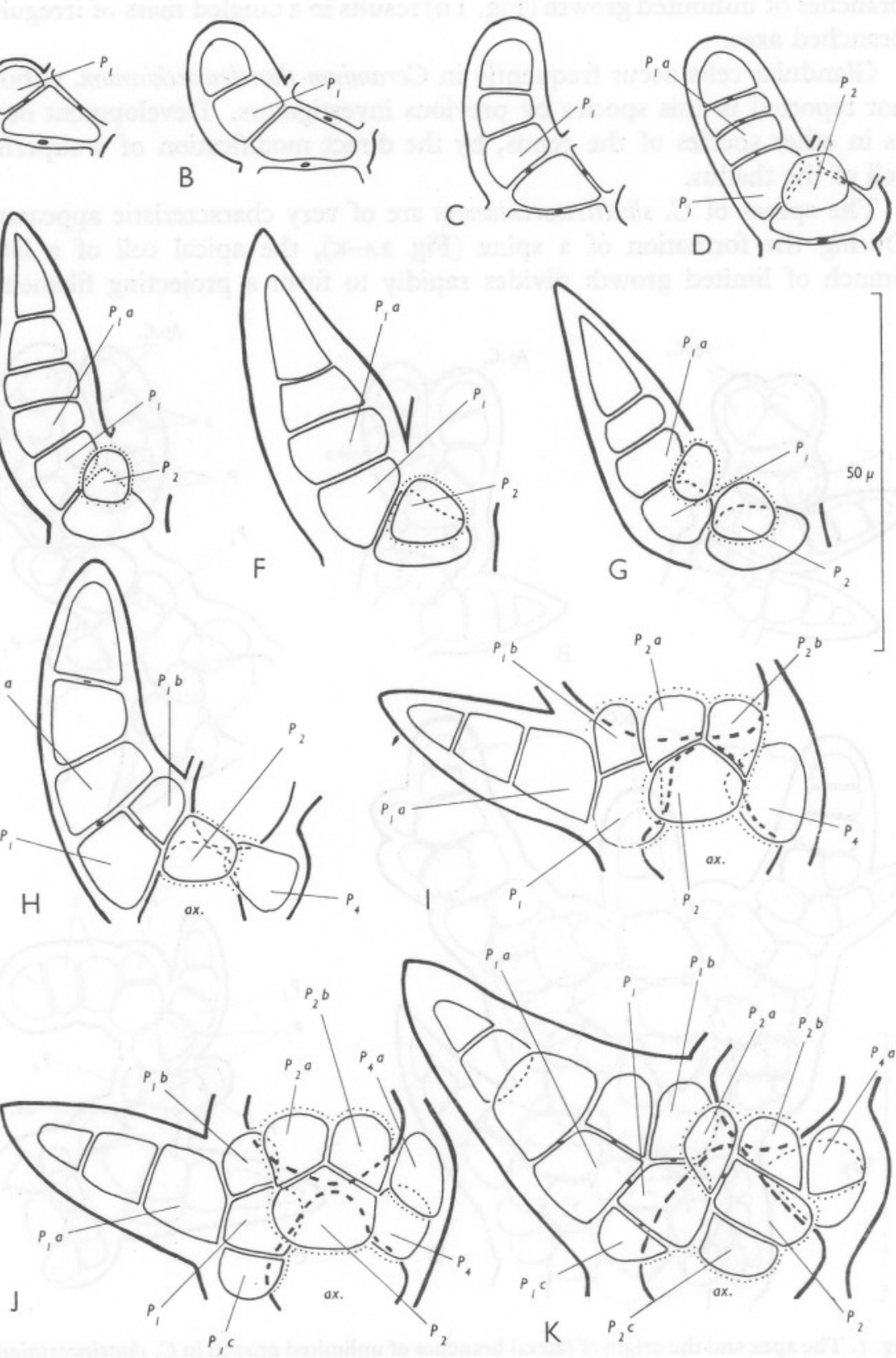

Fig. 2. A-K, Details of the stages in the development of the cortical band, in C. shuttleworthianum. ax., axial cell; $P_{1}, P_{2}$, etc., pericentral cells, numbered in order of formation; $P_{1} a, P_{1} b$, acropetally-directed apical cells of lateral branches of limited growth, produced from $P_{1} ; P_{1} c, P_{1} d$, basipetally directed apical cells of lateral branches of limited growth, produced from $P_{1}$, etc. 
three to five cells. The rapid development of the spines is indicated by the occurrence of fully developed spines within one or two segments of the apex of an axis. The lowermost cells of the filament divide transversely to form part of the cortical band, whilst the other cells of the filament, that is, those cells which project to form the spine, may divide transversely also, so that the spine is conical in shape, with a broad multicellular base. The cells of the spine do not enlarge excessively, as in some other spine-bearing species of

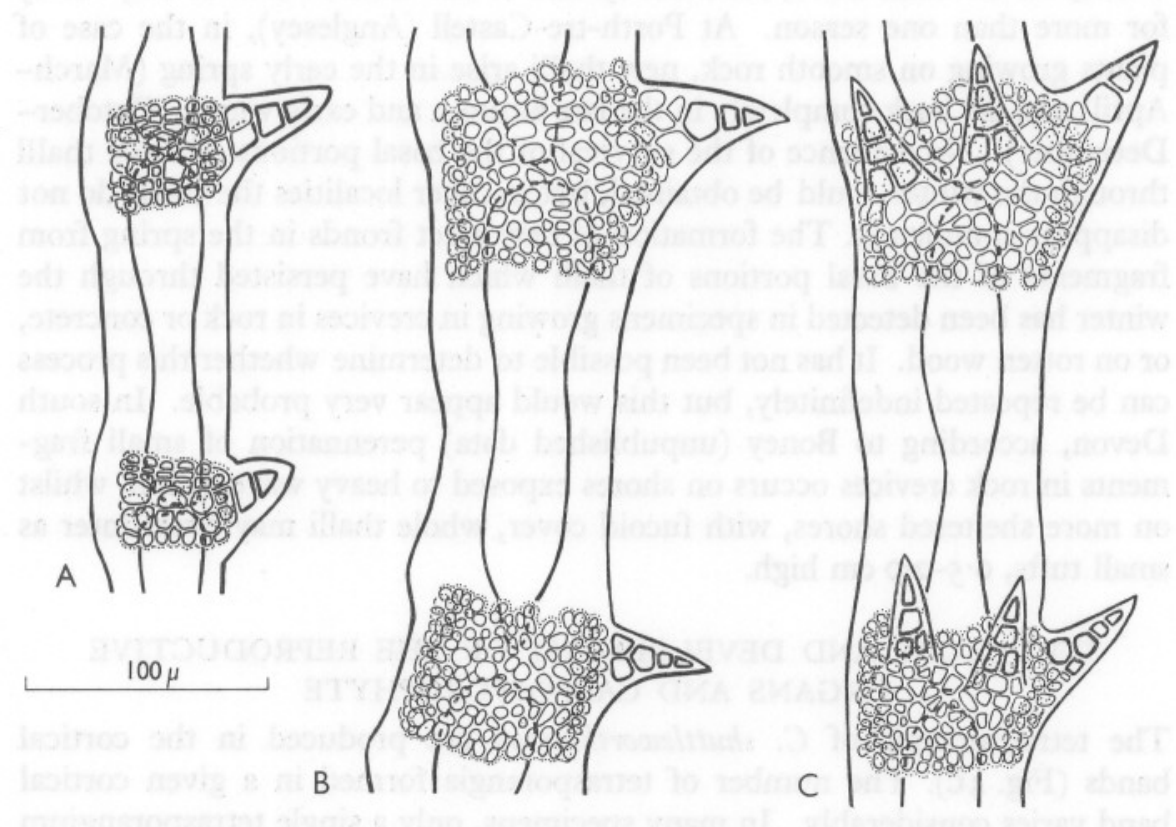

Fig. 3. A-C, Range of form of the axes in C. shuttleworthianum.

Ceramium. Moreover, the chromatophores and cytoplasmic contents are retained so that the cells of the spine resemble the cells of the cortical bands. As a result, the boundary between spine and cortical band is not sharply defined, as in many of the spine-bearing species of Ceramium, and the spines merge with the cortical bands in C. shuttleworthianum (Fig. 3).

Adventitious spines may develop occasionally from the cortical bands of old mature axes. Such spines, which resemble the primary spines in appearance, occur most frequently in specimens which have been grazed by animals or damaged in some other way.

The number of spines occurring at each cortical band is not constant. In every cortical band, a single spine is formed in relation to the first pericentral cell, but other spines may develop in relation to the other pericentral cells, or arise in an adventitious manner. In the extreme case, a whorled arrangement 
of spines may result ( = var. coronata Kleen, I874). The taxonomic significance of these observations will be discussed later (see p. 386).

The life-span of the thalli of $C$. shuttleworthianum is extremely variable. At certain localities in the west of Ireland it would appear that many of the thalli are perennial; Boney (unpublished data) has reported the perennation of large thalli in south Devon. From herbarium collections, it is obvious that in France thalli can survive through the winter. In northern England and Wales, on the other hand, the erect system of the thallus survives only rarely for more than one season. At Porth-tre-Castell (Anglesey), in the case of plants growing on smooth rock, new thalli arise in the early spring (MarchApril) and die back completely in the late autumn and early winter (OctoberDecember). No evidence of the survival of the basal portions of these thalli through the winter could be obtained, but in other localities the thalli do not disappear completely. The formation of new erect fronds in the spring from fragments of the basal portions of thalli which have persisted through the winter has been detected in specimens growing in crevices in rock or concrete, or on rotten wood. It has not been possible to determine whether this process can be repeated indefinitely, but this would appear very probable. In south Devon, according to Boney (unpublished data) perennation of small fragments in rock crevices occurs on shores exposed to heavy wave action, whilst on more sheltered shores, with fucoid cover, whole thalli may overwinter as small tufts, $0.5-2.0 \mathrm{~cm}$ high.

\section{STRUCTURE AND DEVELOPMENT OF THE REPRODUCTIVE ORGANS AND CARPOSPOROPHYTE}

The tetrasporangia of $C$. shuttleworthianum are produced in the cortical bands (Fig. 4C). The number of tetrasporangia formed in a given cortical band varies considerably. In many specimens, only a single tetrasporangium develops in each band, on the outer side of the axis relative to the previous pseudo-dichotomy. Frequently several tetrasporangia develop in each band, and in the extreme condition a whorled arrangement results. The mature tetrasporangia measure $50-100 \times 20-40 \mu$ and when fully developed they are usually only partially immersed in the cortical band (Fig. 4C). The cortical bands of $C$. shuttleworthianum are relatively small and the internal development of the tetrasporangia causes extensive distortion, so that the orientation of the spines is changed considerably.

Spermatangia are produced superficially from mother-cells derived from the apical cells of the lateral branches of limited growth. Frequently the whole surface of the cortical band is covered with spermatangia (Fig. 4B) and when a large number of cortical bands is involved then the thallus develops a very characteristic indefinite outline which is readily identifiable.

No detailed studies have been made previously of the structure and development of the carpogonial branch and carposporophyte of C. shuttleworthianum, 
although Miranda (1929b) has stated that the carpogonial branch and carposporophyte resemble those of $C$. flabelligerum (Miranda, 1929a). Despite the abundance of carposporophytic material of $C$. shuttleworthianum in Ireland, the Channel Islands and the Isle of Man, the collection of specimens of this species with carpogonial branches and young stages of carposporophyte

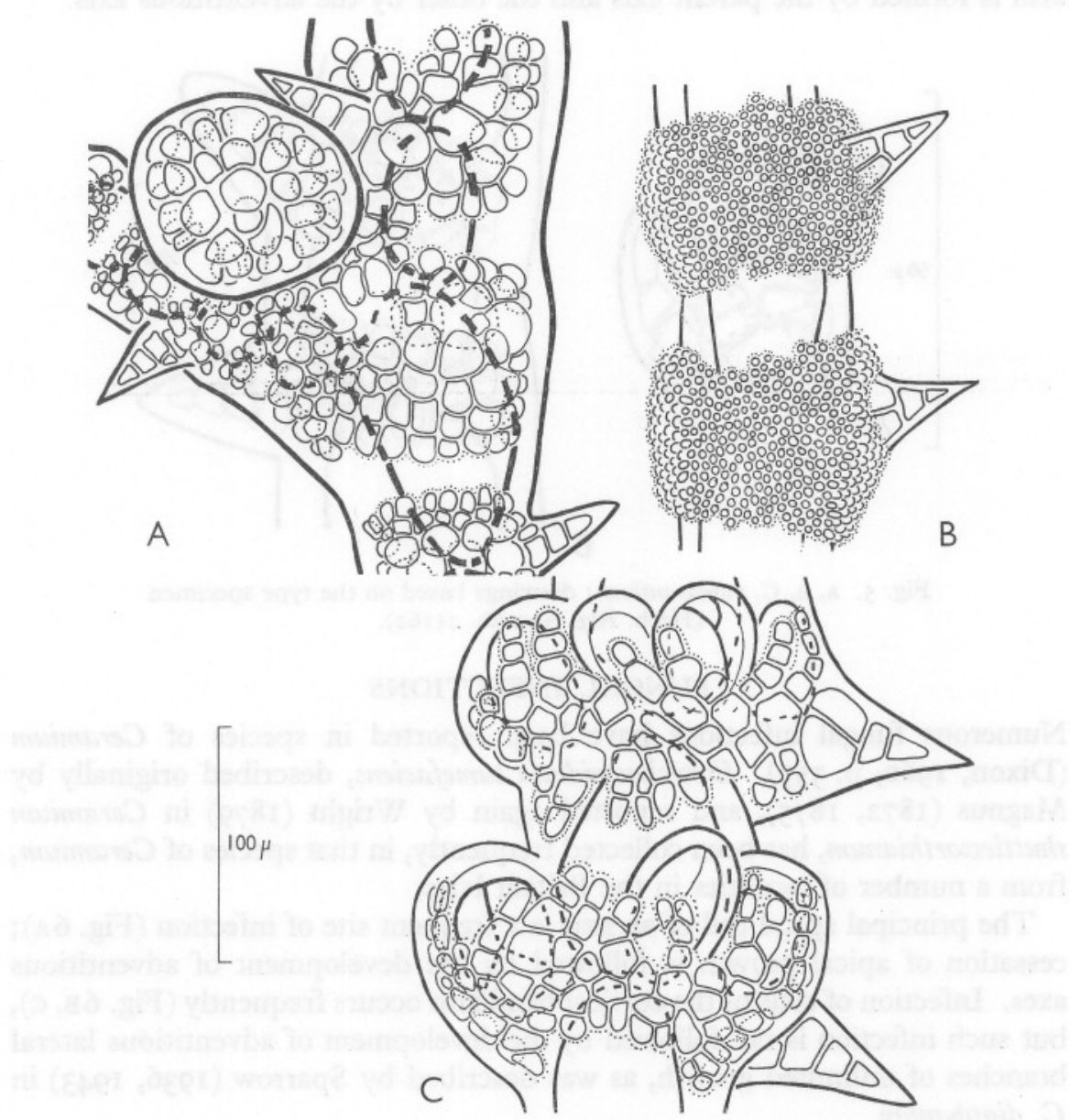

Fig. 4. A-C, Reproductive structures in C. shuttleworthianum.

development was found to be particularly difficult. In seven years, only a single suitable specimen was collected. From this one specimen it would appear that the carpogonial branch is of the characteristic four-celled structure and that the supporting cell is formed by the modification of a first-formed pericentral cell. The lack of suitable material has prevented any detailed study of the carposporophyte development. The mature carposporophyte is 
typical (Fig. 7A), but it differs from that of many other species of the genus in that it is subtended by only a single adventitious lateral branch of unlimited growth. In most species of Ceramium the mature carposporophyte is a lateral structure which is enveloped by a cluster of encircling adventitious axes, but in C. shuttleworthianum it appears to lie in a dichotomy of which one arm is formed by the parent axis and the other by the adventitious axis.

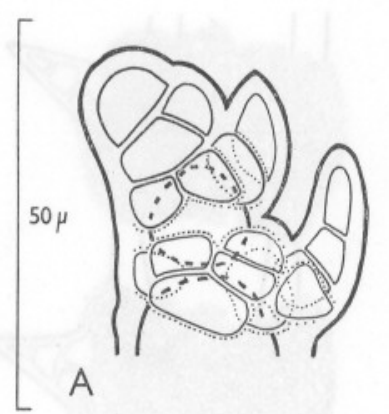

B

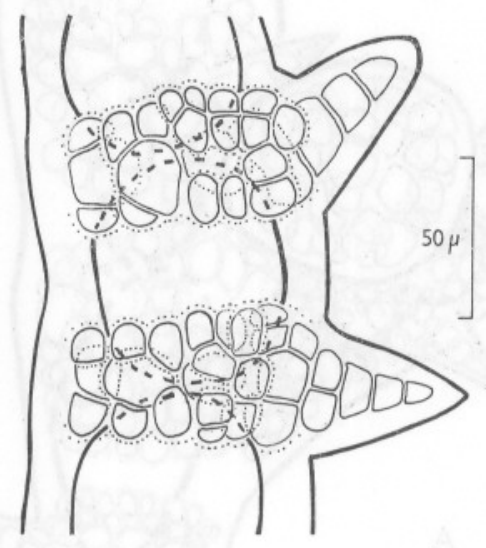

Fig. 5. A, B, C. monacanthum; drawings based on the type specimen (Herb. Alg. Agardh. 21162).

\section{FUNGAL INFECTIONS}

Numerous fungal infections have been reported in species of Ceramium (Dixon, I960, p. 359). Eurychasmidium tumefaciens, described originally by Magnus (1872, I875), and reported again by Wright (1879) in Ceramium shuttleworthianum, has been collected frequently, in that species of Ceramium, from a number of localities in the British Isles.

The principal apical cell of an axis is a frequent site of infection (Fig. 6A); cessation of apical growth is followed by the development of adventitious axes. Infection of cells of the cortical band also occurs frequently (Fig. 6B, C), but such infection is not followed by the development of adventitious lateral branches of unlimited growth, as was described by Sparrow $(1936,1943)$ in C. diaphanum.

\section{DISTRIBUTION}

Many previous records are incorrect because of confusion with other species of the genus. The following data are based upon examined specimens only.

\section{British Isles}

C. shuttleworthianum is generally distributed throughout the British Isles. Specimens from the following counties have been examined: Cornwall, Devon, 
Somerset, Dorset, Hampshire, Kent, Essex, York, Northumberland, Cumberland; Isle of Man; Glamorgan, Carmarthen, Pembroke, Cardigan, Merioneth, Caernarvon, Anglesey, Denbigh; Wigtown, Ayr, Bute, Renfrew, Argyll, Inverness, Ross and Cromarty, Sutherland, Caithness, Moray, Banff, Aberdeen, Fife, West Lothian, Midlothian, East Lothian, Berwick; Orkney, Shetland; Donegal, Sligo, Mayo, Galway, Clare, Kerry, Cork; Channel Islands.

Previous reports of the occurrence of this species in Norfolk, Durham and Cheshire have not been confirmed.

\section{World}

Iceland, Faroes, northern, central and southern Norway, and the Atlantic coast of France.

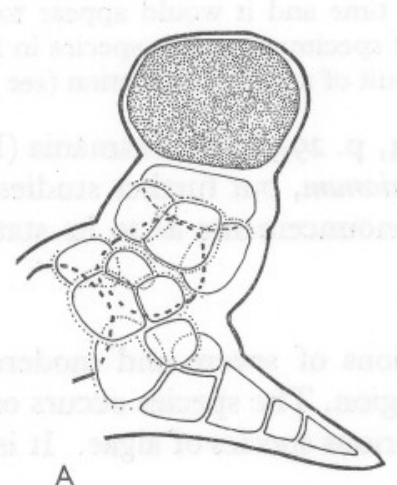

A

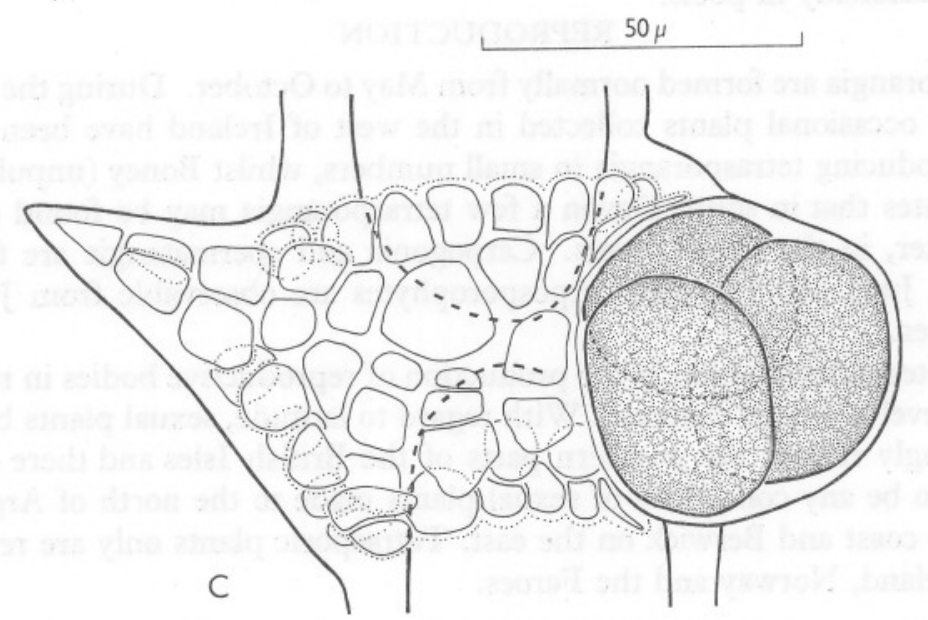

Fig. 6. A-C, Occurrence of Eurychasmidium tumefaciens in C. shuttleworthianum. A, Infection of the apical cell; B, infection of a cortical cell in a young cortical band; c, infection of a cortical cell in an old cortical band. 
The southern limit of the species cannot be stated with certainty. Miranda (1929b) has claimed that the species occurs on the north coast of Spain, but this report must be treated with caution as no illustration is given by Miranda and it has not been possible to locate any specimens of $C$. shuttleworthianum from the area cited by this author. According to Børgesen (I930), the report of the occurrence of this species in the Canary Islands, by Sauvageau (1912, p. 184), is based on a misidentification; the specimens on re-examination proved to be a mixture of $C$. ciliatum and $C$. flabelligerum.

With regard to the northern limit of the species, it is obvious, from a study of the description and figure given by Sinova (I9I2), that the reported occurrence of this species in the Murmansk area is also based upon a misidentification.

It would appear that $C$. shuttleworthianum does not occur on the coasts of Germany (Migula, 1909) or Denmark (Rosenvinge, 1924), although it should be noted that Kützing ( 1845 , p. 293) records the species from the island of Föhr, in the North Friesian archipelago. This record is based, according to Kützing, on a specimen collected by Frölich and identified by him as 'Ceramium diaphanum'. This specimen is not in the Kützing herbarium at the present time and it would appear to be lost completely. The report of the occurrence of drift specimens of this species in Holland (Lucas, 1950) must be discounted, as it is the result of a misidentification (see p. 387).

Ceramium monacanthum ${ }^{1}$ J. Agardh (1894, p. 29), from Tasmania (Fig. 5), bears a close resemblance to $C$. shuttleworthianum, but further studies of the former species are required before any pronouncements as to its status can be made.

\section{HABITAT}

C. shuttleworthianum occurs, under conditions of severe and moderate exposure, throughout the lower mid-littoral region. The species occurs on rock, or on Mytilus, Balanus and Patella, or on various species of algae. It is found only occasionally in pools.

\section{REPRODUCTION}

Tetrasporangia are formed normally from May to October. During the winter months, occasional plants collected in the west of Ireland have been found to be producing tetrasporangia in small numbers, whilst Boney (unpublished data) states that in south Devon a few tetrasporangia may be found during the winter, in the larger plants. Carpogonia and spermatangia are formed in May, June and July and carposporophytes are observable from June to December.

No detectable variation in the production of reproductive bodies in relation to tide level has been observed. With regard to latitude, sexual plants become increasingly rare in the northern parts of the British Isles and there do not appear to be any collections of sexual plants made to the north of Argyll on the west coast and Berwick on the east. Tetrasporic plants only are reported from Iceland, Norway and the Faroes.

${ }^{1}$ For details of the type specimen, see Appendix. 


\section{LIFE HISTORY}

Little is known of the life history of $C$. shuttleworthianum. From personal observations, equal proportions of sexual and tetrasporic plants have been detected in a number of localities on the west coast of Ireland, southern England and the Channel Islands, although, in the same locality, variations in the proportions of sexual and tetrasporic plants have been noticed from year to year. The observations of Boney (unpublished data) in south Devon, on the other hand, indicate a preponderance of tetrasporic plants in that region. In north Wales, northern England, the Isle of Man and parts of Scotland sexual plants are relatively rare, whilst they are unknown in northern Scotland, Norway, Faroes and Iceland. The occurrence of sexual and tetrasporic plants in equal proportions suggests that the life history is of the 'Polysiphoniatype', with a regular alternation of sexual, carposporic and tetrasporic phases, but from the data presented above it would appear very probable that the sequence of phases in the life history may vary considerably over the range of the species.

The regeneration of new thalli from small fragments of the basal portions of old thalli of $C$. shuttleworthianum has been demonstrated. In certain localities, such regeneration occurs frequently, whilst in others it would appear to be relatively rare. The occasional occurrence of extensive perennation in any locality could have a profound effect upon the frequency of occurrence of sexual and tetrasporic phases, in that it could obscure the actual sequence of phases in a life history, or introduce deviations from the proportions of sexual and tetrasporic phases to be expected in a life history of the 'Polysiphonia-type'.

\section{FORM RANGE}

Ceramium shuttleworthianum is one of the least polymorphic species of the genus. In the British Isles the dimensions of the thalli vary considerably, but the variation appears to result more from the effects of damage and the subsequent regeneration than from any other cause, although the degree of enlargement of the axial cells has some effect upon the size of the thallus. The species occurs throughout the lower mid-littoral region, but there is no detectable range of form in relation to tide level and it would appear very probable that this results from the extensive damage, which occurs at all levels, obscuring any effect of tide level on the form of the thallus. The species is found in pools only rarely. The specimens from pools are larger and more regularly branched than other specimens growing out of water at the same tide level.

Most specimens of $C$. shuttleworthianum collected in the British Isles develop a single spine at each cortical band (Fig. 3 A, B), but occasionally a number of spines occur, forming a partial or complete whorl (Fig. 3C). 
Kleen (1874, p. 19) proposed that such specimens should be separated as C. acanthonotum var. coronata. Kjellman (1883, p. I72), after a re-examination of Kleen's original material, ${ }^{1}$ reduced the status of this variety to forma coronata, with the following remarks: 'In Kleen's collections only the typical form of Ceramium acanthonotum is to be found, but some specimens have the spines in certain parts of the frond so arranged as in the variety distinguished by Kleen. This variety resembling the typical form in all respects... it may be considered as rather little independent, though it deserves perhaps to be specially mentioned.'

Specimens with the spines in whorls have been reported from Norway (Kleen, 1874; Foslie, I894) and Faroes (Børgesen, I902), but apparently not from Iceland (Jónsson, 1902). From the literature it might appear that the number of spines formed at each cortical band is related to latitude. This opinion must be rejected for a number of reasons. First, over the whole range of the species there is little constancy in the number of spines produced, so that adjacent cortical bands in the same axis may bear a single spine or a whorl of spines; secondly, all intermediate states between the two extremes occur also, and thirdly, the whorled condition may result from the formation of a number of primary spines or from the subsequent development of secondary adventitious spines.

From this discussion it is obvious that there is no justification for the taxonomic separation of those thalli in which more than one spine is formed in each cortical band.

Kützing (1862) figured Acanthoceras shuttleworthianum $\beta$ longiarticulatum, reputedly characterized by the extreme length of the axial cells in the mature parts of the thallus. ${ }^{2}$ That there is no justification for the separation of $\beta$ longiarticulatum is obvious, even from the original illustrations given by Kützing (1862, pl. 96, figs. a-f). Kützing gives a figure (pl. 96, fig. c) of the basal portions of $A$. shuttleworthianum and two figures (pl. 96, figs. e, f) of the basal portions of $A$. shuttleworthianum $\beta$ longiarticulatum. Calculation of the 'index of cortication' for these three illustrations gives a mean value of 3.66 for A. shuttleworthianum and values of $\mathrm{I} \cdot 25$ and 4.25 for the two illustrations of $\beta$ longiarticulatum. Examination of Kützing's original material of $\beta$ longiarticulatum shows that the range of variation of the index of cortication in these specimens is from 0.75 to 5.0 , which is not significantly different from the range in the species as a whole, based upon a series of measurements of a large number of specimens from a wide range of localities. There is thus no justification for the separation of this variety.

${ }^{1}$ For comments on the type material of this variety, see Appendix.

${ }^{2}$ For a discussion of the type material and validity of publication of this entity, see Appendix. 


\section{THE INTERRELATIONSHIPS OF CERAMIUM CILIATUM AND CERAMIUM SHUTTLEWORTHIANUM}

C. shuttleworthianum has been confused only with C. ciliatum. Harvey (in Hooker, I833) regarded the species originally as a variety of C. ciliatum and this opinion has been repeated recently by Lucas (1950), who states: 'It is doubtful whether $C$. acanthonotum is a good species, for sometimes parts with whorls of spines and parts with spines on the outer side of the node only are found on the same plant.' It is obvious that a detailed study of the interrelationships of these two species is necessary if this confusion is to be overcome.

The two species were distinguished originally on the basis of spine distribution. It was supposed that in C. ciliatum the spines occur in whorls, whilst in $C$. shuttleworthianum a single spine occurs in each cortical band. From the previous discussion it is clear that more than one spine may occur in the cortical band of $C$. shuttleworthianum, whilst in C. ciliatum, although the spines occur frequently in whorls, there may be a reduction in the number of spines, so that in extreme cases only a single spine occurs at each cortical band. From this evidence it would appear that the separation of the two species is not justified. Careful investigation shows that this conclusion is incorrect, and that, although the distribution of spines is of little taxonomic significance, the two species are completely distinct.

In connexion with the opinions expressed by Lucas (1950), it should be noted that the re-examination of his material, now in the Rijksherbarium, Leiden, shows that the statement of this author as to the status of $C$. shuttleworthianum must be discounted, as none of the specimens identified by him as ' $C$. acanthonotum' is of this entity; the specimens are of $C$. ciliatum, with a reduced number of spines.

The morphology of the spine is the most obvious character by which the two species can be distinguished. In C. shuttleworthianum, each spine is a conical structure, composed of from three to ten cells, two to four cells broad at the base (Fig. 3). The cells of the spine are of similar size (15-25 $\mu$ in diameter) and they retain their chromatophores and cytoplasm throughout the life of the plant. In C. ciliatum, the spine is formed of a uniseriate filament of three, or occasionally four or five, cells which differ markedly in size (Fig. 7). In mature three-celled spines the lowermost cell occupies more than half the length of the spine $(30-50 \mu \times 20-30 \mu)$, the second cell is smaller $(20-30 \mu \times 10-20 \mu)$, whilst the third cell is minute and triangular in shape. In four- and five-celled spines the differences in size between the cells of the spine are not so marked as in three-celled spines, but the lowermost cell is always the largest, whilst the terminal cell is always small and triangular. When first formed, the cells of the spine of $C$. ciliatum have dense cytoplasm and chromatophores, but as a result of the enormous increase in cell-size which takes place during development, the mature cells are frequently 
hyaline, although occasionally the remnants of cytoplasm and chromatophores may remain, forming curious patterns on the wall of the cell (see FeldmannMazoyer, 1940, fig. 55).

The two species may also be distinguished by the number of pericentral cells formed by each segment of a principal apical cell. Four pericentral cells are formed in C. shuttleworthianum, whilst six to eight are formed in C. ciliatum.

The two species can be distinguished, even in the field, by their size; with a good hand lens, the construction of the spine is clearly visible.

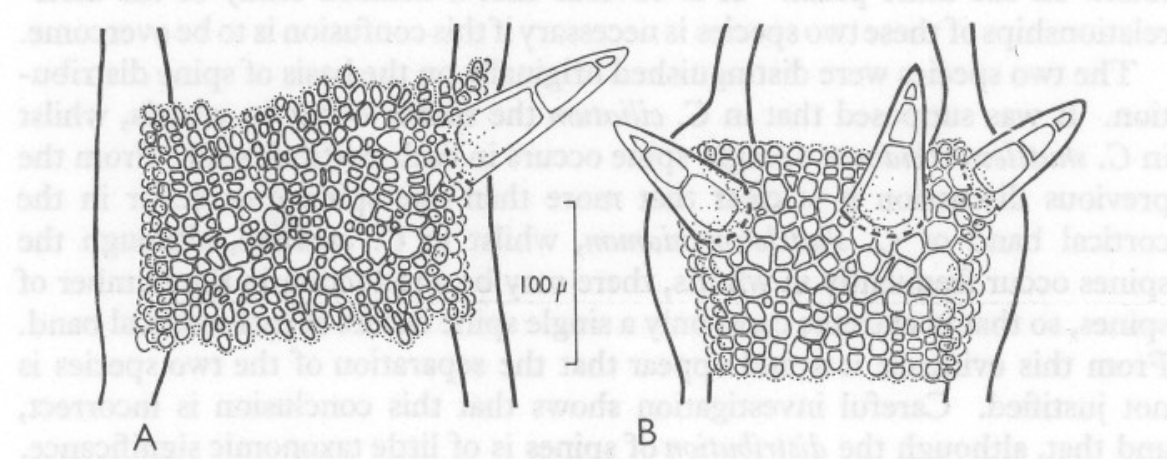

Fig. 7. A, B, Distribution of spines in Ceramium ciliatum.

\section{APPENDIX}

NOTES ON TYPE SPECIMENS

Acanthoceras shuttleworthianum $\beta$ longiarticulatum Kützing, 1862, p. 29

Kützing's original reference to $A$. shuttleworthianum $\beta$ longiarticulatum is extremely brief,

'3076. Acanthoceras Shuttleworthianum $\beta$ longiarticulatum.-Ad oras Angliae.'

but, as this is accompanied by an illustration (Kützing, I862, pl. 96, figs. d-f) showing the essential characters, the name must be regarded as validly published [see Article 43 of the International Code of Botanical Nomenclature (Lanjouw, 1956)]. According to manuscript notes written by Kützing on a packet, containing four clumps of material, now in the Rijksherbarium, Leiden (Herb. Lugd. Bat. 940.265.154), the entity was based upon material collected by Dickie at Aberdeen. The four clumps of material are mounted on three pieces of card, each of which is labelled, in Dickie's hand, 'Ceramium acanthonotum Carm Aberdeen Sept. I845 GD'. A lectotype has been selected from the material available.

Location of lectotype: Rijksherbarium, Leiden (L), as Herb. Lugd. Bat. 940.265.I54. Location of syntypes: as above. Locality of the type material: Aberdeen, Scotland.

\section{Ceramium acanthonotum var. coronata Kleen, 1874 , p. 19}

It has not been possible to locate the original material of this variety, as the present location of Kleen's herbarium is unknown. It is obvious from the various comments made by Kjellman ( 1883 ) that he had examined numerous specimens from the Kleen herbarium, but no mention is made of the location of the herbarium. Only a single Kleen 
specimen of the species has been located, in the Rijksherbarium, Leiden (Herb. Lugd. Bat. 940.265.25). This specimen, labelled in Kleen's hand 'Cer acanthonotum Carm Nordlanden', is from the same geographical area as the type material, but from the label it would not appear to be part of it. In the absence of type material, the illustrations given by Kleen (1874, Taf. 10, figs. $5 a, b$ ) are adequate for the purposes of identification.

Location of type specimen: unknown. Locality of type material: Nordlanden, Norway.

Ceramium ciliatum $\beta$ acanthonotum Carm. ex Harv. in Hooker, I833, p. 236

Several Carmichael specimens of $C$. acanthonotum have been located in herbaria. Neither Carmichael nor Harvey designated a holotype and no information can be obtained from the specimens, all of which are labelled, in Carmichael's hand, 'Carmichael $\mathrm{H} / \mathrm{A}^{\prime}$ ( = 'Herbarium Appinensis'). A lectotype has been selected from the material available.

Location of lectotype: Herbarium, Royal Botanic Gardens, Kew (K). Location of syntypes: as above (2 specimens). Herbarium, Royal Botanic Garden, Edinburgh (E) (I specimen). Locality of the type material: Appin, Argyle, Scotland.

Ceramium monacanthum J. Agardh, I894, p. 29

The species was based on a single specimen collected by Roland Gunn in Tasmania.

Location of holotype: Botaniska Museet, Lund (LD), (as Herb. Alg. Agardh. 2I162); Tasmania (no further details known).

\section{ACKNOWLEDGEMENTS}

I am indebted to Dr M. T. Martin for her encouragement and critical observations; to Prof. N. A. Burges, Dr E. M. Burrows and Dr M. W. Parke for advice and helpful criticism; to Dr A. D. Boney for permission to make use of unpublished data; to $\mathrm{Mr} \mathrm{R}$. Ross for assistance with nomenclatural matters and to Mrs Y. Butler, Miss C. I. Dickenson and Dr J. Th. Koster for help with literature and specimens. I would like to thank the Joint Committee on Research of the University of Liverpool for financial help towards the cost of visiting herbaria and libraries, and the Directors and Curators of the following herbaria for permission to examine specimens: British Museum (Natural History); Royal Botanic Gardens, Kew; Royal Botanic Garden, Edinburgh; Rijksherbarium, Leiden; Naturhistoriska Rijksmuseum, Stockholm; Museum Nationale d'Histoire Naturelle, Paris; Botaniska Museet, Lund.

The British Phycological Society has made a grant to the Marine Biological Association towards the cost of publication of these Studies.

\section{REFERENCES}

Agardh, J. G., I844. In Systemata Algarum hodierna adversaria. 56 pp. Lund.

I 1894 . Analecta algologica. Observationes de speciebus algarum minus cognitis earumque dispositione. Continuatio II. Acta Univ. lund., Bd. 30, No. 7, pp. I-99. BøRGeSEN, F., I902. The marine algae of the Faeroes. In Warming, E., Botany of the Faeroes, Vol. 2, pp. 339-532. 
1930. Marine algae from the Canary Islands especially from Teneriffe and Gran Canaria. III. Rhodophyceae. Part III. Ceramiales. Biol. Medd., Kbh., Bd. 9, No. I, pp. I-59.

Dixon, P. S., 1959. Taxonomic and nomenclatural notes on the Florideae. I. Bot. Notiser, Vol. I12, pp. 339-52.

- 1960. Marine algae of the British Isles: the genus Ceramium. F. mar. biol. Ass. U.K., Vol. 39, pp. 33I-374.

Feldmann-Mazoyer, G., 1940. Recherches sur les Céramiacées de la Mediterranée occidentale. 5 Io pp. Alger.

FosLIE, M., I894. The Norwegian forms of Ceramium. K. norske vidensk. Selsk. Skr., I893, pp. I-2I.

HOOKER, W. J., I833. The English Flora of Sir fames Edward Smith. Class XXIV, Cryptogamia, Vol. 5, $\mathrm{x}+432$ pp. London.

Jónsson, H., 1902. The marine algae of Iceland. I. Rhodophyceae. Bot. Tidsskr., Bd. 24, pp. 127-55.

KJellman, F. R., I883. The algae of the Arctic Sea. A survey of the species, together with an exposition of the general characteristics and the development of the flora. K. svenska VetenskAkad. Handl., Bd. 20, No. 5, pp. I-35I.

KLEEN, A. E., I874. Om Nordlandens högre hafsalger. Ofvers. VetenskAkad. Förh., Stockh., 1874, No. 9, pp. 3-46.

KÜTZING, F. T., I84I. Ueber Ceramium Ag. Linnaea, Bd. I5, pp. 727-46.

- 1845. Phycologia germanica, die im Deutschlands algen in bundigen Beschreiben. $\mathrm{x}+340$ pp. Nordhausen.

- 1862. Tabulae Phycologicae, oder Abbildungen der Tange, Bd. 12, iv + 30 pp., I00 pls. Nordhausen.

Lanjouw, J., 1956. International Code of Botanical Nomenclature.... 338 pp. Utrecht.

LUCAS, J. A. W., I950. The algae transported on drifting objects and washed ashore on the Netherlands' coast. Blumea, Vol. 6, pp. 527-43.

MaGnUS, P., 1872. Ueber Chytridium tumefaciens n.sp. in den Wurzelhaaren von Ceramium flabelligerum und acanthonotum und andere in Meeresalgen lebende. S.B. Ges. naturf. Fr. Berl., pp. 87-90.

- 1875. Die botanische Ergebnisse der Nordseefahrt von 2I Juli bis 9 Sept. I872. Wiss. Meeresuntersuch., Bd. 2, pp. 59-80.

Migula, W., 1909. Kryptogamen-flora von Deutschland, Deutsch-Osterreich und der Schweiz, Bd. II, Algen, T. 2, Rhodophyceae, Phaeophyceae, Characeae, 383 pp. Leipzig.

MirandA, F., I929a. El desarrollo del cistocarpio en una Ceramiácea (Ceramium flabelligerum J. Ag.). Bol. Soc. esp. Hist. nat., T. 29, pp. 47-52.

- 1929b. Contribuciones algológicas. Mem. Soc. esp. Hist. nat., T. 15, pp. 487-9.

Rosenvinge, L. K., I924. The marine algae of Denmark. Vol. I, Part III. Rhodophyceae III (Ceramiales). K. danske vidensk. Selsk., Raekke 7, Bd. 7, pp. 287-486.

Sauvageau, C., I9I2. A propos des Cystoseira de Banyuls et de Guéthary. Bull. Soc. sci. Arcachon, T. I4, pp. 133-556.

Silva, P. C., 1959. Remarks on algal nomenclature. II. Taxon, Vol. 8, pp. 60-4.

Sinova, E. S., 1912. Algae Murmanicae, Chlorophyceae et Rhodophyceae [text in Russian]. Trav. Soc. Nat. St-Pétersb., Sér. 3, T. 43, pp. I7I-343.

Sparrow, F. K., 1936. Biological observations on the marine fungi of Woods Hole. Biol. Bull., Woods Hole, Vol. 70, pp. 236-63.

- 1943. Aquatic phycomycetes exclusive of the Saprolegniaceae and Pythium. xv + 785 pp. Ann Arbor.

WRIGHT, E. P., 1879. On a new species of parasitic green alga belonging to the genus Chlorochytrium of Cohn. Trans. R. Irish Acad., Vol. 26, pp. 355-68. 